\title{
Nutritional Deficiency in Patients with Heart Failure
}

\author{
Edoardo Sciatti, Carlo Lombardi *, Alice Ravera, Enrico Vizzardi, Ivano Bonadei, \\ Valentina Carubelli, Elio Gorga and Marco Metra \\ Cardiology, Department of Medical and Surgical Specialties, Radiological Sciences and Public Health, \\ University of Brescia, Piazzale Spedali Civili 1, Brescia 25123, Italy; edoardo.sc@tin.it (E.S.); \\ ravera.alice@gmail.com (A.R.); enrico.vizzardi@tin.it (E.V.); ivano.bonadei@libero.it (I.B.); \\ valentina.carubelli@gmail.com (V.C.); eliogorga@yahoo.it (E.G.); metramarco@libero.it (M.M.) \\ * Correspondance: lombardi.carlo@alice.it; Tel.: +39-030-399-5536; Fax: +39-030-399-5013
}

Received: 26 March 2016; Accepted: 15 July 2016; Published: 22 July 2016

\begin{abstract}
Heart failure (HF) is the main cause of mortality and morbidity in Western countries. Although evidence-based treatments have substantially improved outcomes, prognosis remains poor with high costs for health care systems. In patients with HF, poor dietary behaviors are associated with unsatisfactory quality of life and adverse outcome. The HF guidelines have not recommended a specific nutritional strategy. Despite the role of micronutrient deficiency it has been extensively studied, data about the efficacy of supplementation therapy in HF are not supported by large randomized trials and there is limited evidence regarding the outcomes. The aim of the present review is to analyze the state-of-the-art of nutritional deficiencies in HF, focusing on the physiological role and the prognostic impact of micronutrient supplementation.
\end{abstract}

Keywords: heart failure; nutritional deficiency; metabolism; iron; amino acids; coenzyme Q10; cardiac cachexia

\section{Introduction}

Heart failure (HF) is the main cause of mortality and morbidity in Western countries [1]. Acute HF (AHF) is the leading cause of hospitalization in the Unites States and Europe. HF patients have multiple comorbidities such as renal dysfunction, pulmonary disease, anemia and depression, which influence the prognosis [2]. Despite the introduction over the last 20 years of renin-angiotensin-aldosterone (RAA) system antagonists, beta-blockers and devices have improved the outcomes, the quality of life and the functional capacity remains extremely poor, especially in the advanced stages of the disease $[1,3]$. The mortality and hospitalization rates remain unacceptably high also due to lack of effective new therapies in AHF [4,5].

The unsatisfactory quality of life emphasizes depression, discontinuation of therapy, and insufficient intake of nutrients [6-8]. In patients with HF, the increased risk of poor dietary intake is associated with lower quality of life, which predicts cardiovascular events $[9,10]$. However, the HF guidelines have not recommended specific nutritional strategies, despite growing evidence regarding the important role of micronutrient deficiencies in chronic HF [1,11]. Clinical research investigating the effects of micronutrient supplementations on the outcomes is still limited. The lack of general recognized nutritional strategies aimed at improving the quality of life and functional capacity remains an unmet need in HF research.

The aim of the present review is to analyze the state-of-the-art of nutritional deficiency in HF, focusing on the evidence regarding the physiological role and the prognostic impact of supplementation therapies in HF patients. 


\section{Metabolism Deficiencies in Heart Failure}

The failing heart is an energy-compromised organ, characterized by "metabolic remodeling" [12]. Abnormalities in myocardial substrate utilization and energy metabolism, including a decline in adenosine triphosphate (ATP), mitochondrial dysfunction, and the increase in free fatty acid concentration, are directly correlated with the progression of HF [13-16]. The shift toward carbohydrate utilization from fatty acids (FAs) oxidation represents a fetal metabolic phenotype activated by the expression of specific fetal genes $[17,18]$. The over-expression of fetal genes reduced the cardiac efficiency by converting chemical energy into mechanical work $[19,20]$. In addition, ischemia and oxidative stress may further reduce energy expenditure, resulting in cardiomyocyte injury [21,22].

Several micronutrients are essential cofactors of metabolic reactions and contribute to the efficiency and the appropriate utilization of energy [23]. The genetic deficiencies of L-carnitine, thiamine, and taurine are associated with specific cardiomyopathies [24]. It has also been demonstrated that the failing heart is deficient in several micronutrients [25]. Consequently, the administration of micronutrients should be an attractive option for HF patients.

HF is characterized by loss of muscle mass and function (sarcopenia), and/or loss of tissue mass (cachexia) [26,27]. It has been demonstrated that unintentional weight loss is an independent risk factor for mortality in chronic HF $[28,29]$. Cardiac cachexia is characterized by a catabolic state in which micronutrient supplementation may play a crucial role [30]. Despite this evidence, the efficacy of nutritional intervention is less clear. In the paragraphs below, we analyze the state-of-the-art knowledge about single micronutrient supplementation in HF.

The effects of supplementation in HF patients are reported in Tables 1 and 2, respectively. 
Table 1. Selected studies on the prognostic role of plasmatic concentration of micronutrients in heart failure.

\begin{tabular}{|c|c|c|c|c|c|}
\hline Supplement & First Author, Year & Patients & $\begin{array}{l}\text { Mean/Median Plasmatic } \\
\text { Concentration }\end{array}$ & Prevalence of Deficiency & Prognostic Impact \\
\hline \multirow[t]{2}{*}{ Coenzyme Q10 } & Molyneux, 2008 [31] & $\begin{array}{c}236 \text { hospitalized for } \\
\text { chronic heart failure (HF) }\end{array}$ & $0.68 \mu \mathrm{mol} / \mathrm{L}(0.18-1.75)$ & - & \multirow{2}{*}{$\begin{array}{l}\text { Mortality: hazard ratio (HR) } 2.0 \text { at the ROC } \\
\text { curve cut-point or } 1.6 \text { at the median value } \\
\text { Mortality: HR } 1.5 \text { at univariable analysis, not } \\
\text { confirmed at multivariable one }\end{array}$} \\
\hline & McMurray, 2010 [32] & 1191 ischemic systolic HF & $0.74 \mu \mathrm{g} / \mathrm{mL}(0.56-0.99)$ & - & \\
\hline 25OH-vitamin D & Liu, 2011 [33] & $548 \mathrm{HF}$ & $36.6 \mathrm{nmol} / \mathrm{L}(27.4-51.1)$ & $75 \%$ & $\begin{array}{l}\text { All-cause mortality and HF rehospitalization: } \\
\text { HR } 1.09 \text { per } 10 \mathrm{nmol} / \mathrm{L} \text { decrease; all-cause } \\
\text { mortality: } 1.10 \text { per } 10 \mathrm{nmol} / \mathrm{L} \text { decrease }\end{array}$ \\
\hline Iron & Jankowska, 2010 [34] & $\begin{array}{l}546 \text { stable systolic chronic } \\
\text { HF patients }\end{array}$ & - & $\begin{array}{l}37 \% \pm 4 \%(32 \%+4 \% \text { vs. } 57 \% \\
+10 \% \text { in subjects without vs. } \\
\text { with anemia) }\end{array}$ & Death or heart transplantation: HR 1.58 \\
\hline
\end{tabular}

Table 2. Selected trials about the prognostic effect of micronutrient supplementation in heart failure.

\begin{tabular}{|c|c|c|c|c|c|c|c|}
\hline Supplement & First Author, Year & Type of Study & Patients' Number & Dose & Duration & Survival Outcome & Results \\
\hline Coenzyme Q10 & $\begin{array}{c}\text { Mortensen, } 2014 \\
{[35]}\end{array}$ & $\begin{array}{c}\text { Randomized } \\
\text { controlled trial (RCT) } \\
\text { (Q-SYMBIO trial) }\end{array}$ & 420 (202 vs. 218$)$ & $\begin{array}{c}100 \mathrm{mg} \times 3 / \text { die vs } \\
\text { placebo }\end{array}$ & 106 weeks & $\begin{array}{l}\text { Hospitalization for worsening } \\
\text { heart failure, cardiovascular } \\
\text { death, mechanical assist } \\
\text { implantation, or urgent cardiac } \\
\text { transplantation at two years }\end{array}$ & $43 \%$ risk reduction \\
\hline Vitamin D & Planned & $\begin{array}{l}\text { RCT (EVITA trial, } \\
\text { NCT01326650) }\end{array}$ & 400 & $\begin{array}{l}100 \mathrm{mcg} / \text { die vs. } \\
\text { placebo }\end{array}$ & Three years & $\begin{array}{l}\text { All-cause death at three years; } \\
\text { cardiac transplantation, high } \\
\text { urgent listing for cardiac } \\
\text { transplantation, resuscitation, } \\
\text { hospitalization, ventricular assist } \\
\text { device implantation at three years }\end{array}$ & - \\
\hline Iron & $\begin{array}{c}\text { Jankowska, } 2016 \\
{[36]}\end{array}$ & Meta-analysis & 951 (509 vs. 342) & $\begin{array}{l}\text { Variable vs. } \\
\text { placebo }\end{array}$ & $\begin{array}{c}\text { From five to } 36 \\
\text { weeks }\end{array}$ & $\begin{array}{l}\text { All-cause death or cardiovascular } \\
\text { hospitalization; cardiovascular } \\
\text { death or hospitalization for } \\
\text { worsening heart failure }\end{array}$ & $\begin{array}{l}56 \% \text { risk reduction; } \\
61 \% \text { risk reduction }\end{array}$ \\
\hline L-Carnitine & Rizos, 2000 [37] & Open-label & 80 (42 vs. 38$)$ & $2 \mathrm{~g} / \mathrm{die}$ & Three years & Death at three years & $3 \%$ vs. $18 \%$ \\
\hline
\end{tabular}




\section{Coenzyme Q10}

Coenzyme Q10 (CoQ10) is a natural antioxidant synthesized and diet-supplied lipid-soluble cofactor that acts in the mitochondrial membrane [38]. CoQ10 is present in high concentrations in the mitochondrial electron transport chain (ETC) from complex 1 (NADH coenzyme Q reductase) to complex 3 (cytochrome bc1 complex), and from complex 2 (succinate dehydrogenase) to complex 3 . CoQ10 participates in the synthesis of ATP and in healthy subjects is present in high concentrations in the myocardium [39]. It exerts three main biological roles in humans: contributes to mitochondrial energy production, stabilizes the cell membrane, and has an antioxidant effect [40]. Coenzyme Q10 deficiency is associated with HF. In patients with HF, the reduced intake of CoQ10 is correlated with New York Heart Association (NYHA) functional class, lower left ventricular ejection fraction (LVEF) and increased NT-proBNP levels [32]. In addition, beta-blockers and statins have been proved to reduce CoQ10 plasmatic concentration [41-43]. The administration of CoQ10 on left ventricular function (i.e., LVEF and cardiac output) has been analyzed in several small studies and some double-blinded clinical trials, suggesting a positive role of CoQ10 supplementation evidenced by an improvement (3.7\%) in LVEF [44,45]. Sub-group analysis highlighted the major benefit in lower NYHA classes, LVEF $<30 \%$ and patients not assuming ACEi. Antioxidant effects of CoQ10 may prevent myocytes injury and lipid oxidation due to reactive oxygen species. CoQ10 preserves nitric oxygen release, reducing the peripheral vascular resistances (i.e., afterload) and protecting the myocardium against ischemia [46]. Other studies have evaluated and confirmed the positive role of CoQ10 in symptom relief, $6 \mathrm{~min}$ walking distance (6MWD), exercise duration, peak oxygen consumption and quality of life [47-49].

Observational studies have demonstrated that the serum CoQ10 concentration is an independent predictor of mortality in patients hospitalized for HF, which has not been confirmed in a larger cohort after adjustment for several variables [30,31]. These studies were limited by the small number of patients enrolled and the heterogeneity of clinical endpoints. From 2003 to 2010, 17 centers worldwide conducted the first prospective, randomized, double-blind, placebo-controlled Q-SYMBIO trial regarding CoQ10 as an adjunctive treatment for chronic HF ((100 $\mathrm{mg}$ three times daily) vs. placebo $(n=420))$ [35]. The primary short-term (16 weeks) endpoints were NYHA functional class, 6MWD, and NT-proBNP, while the primary long-term (106 weeks) endpoint was composite major adverse cardiovascular events (MACE, i.e., hospitalization for worsening HF, cardiovascular death, mechanical assist implantation, or urgent cardiac transplantation). CoQ10 added to standard therapy did not affect the short-term endpoint, but significantly reduced the composite endpoints of MACE (15\% vs. $26 \%$, corresponding to a $43 \%$ relative reduction) as well as cardiovascular death, hospitalization for HF, and all-cause death ( $42 \%$ relative reduction). However, despite the high number of studies showing favorable effects of CoQ10 supplementation, a recent systematic review has underlined the frailty of the evidence in HF patients [50]. The authors analyzed seven studies in which coenzyme Q10 was compared with a placebo. Despite minimal improvements in the LVEF values and symptoms, the improvement in outcomes, functional capacity, and brain natriuretic peptide values (BNP) were not confirmed. Larger randomized studies are warranted in order to clarify previous conflicting results.

\section{Vitamin D}

In patients with $\mathrm{HF}$, intracellular ionized calcium $\left(\mathrm{Ca}^{2+}\right)$ utilization is impaired and myocardial contractility is negatively affected [51]. Vitamin D plays an important role in bone mineralization and maintenance of the serum calcium level and its receptors were identified in cardiomyocytes and endothelial cells [52,53]. In animal models with vitamin D deficiency, the administration of calcitriol has improved heart contractility and reduced the natriuretic peptides concentration [54,55]. Moreover, vitamin D suppresses renin production, modulates myocardial and vascular hypertrophy, inhibits inflammatory cytokines, improves endothelial function and reduces atherosclerosis [56-59]. Observational studies have demonstrated that vitamin D deficiency and hyperparathyroidism are common in HF, regardless of age and renal function [60]. In patients with HF renal dysfunction is the most common comorbidity which influences the prognosis and it also represents the main cause 
of vitamin D deficiency [61,62]. Diuretic therapy, insufficient ultraviolet exposure, inadequate intake with diet and/or malabsorption caused by intestinal edema reduce the vitamin D concentration [60]. In addition, TNF- $\alpha$, whose plasmatic levels are higher in HF, abolishes calcitriol synthesis, reducing vitamin D levels $[63,64]$.

Liu et al. investigated the prognostic role of low vitamin D status in 548 HF patients with reduced LVEF [33]. After multivariable adjustment, they demonstrated that $25 \mathrm{OH}$-vitamin D concentration independently predicts the combined endpoint of all-cause mortality and HF hospitalization (HR 1.09 per $10 \mathrm{nmol} / \mathrm{L}$ decreased; $51 \%$ vs. 64\% survival in first and third tertile, respectively) and all-cause mortality alone (HR 1.10; 65\% vs. $79 \%$ survival in first and third tertile, respectively) at 18-month follow-up. In this study, low vitamin D levels were associated with an increase in plasmatic renin activity and C-reactive protein, and even LVEF was inversely related to vitamin D concentration as demonstrated in previous research [65-67].

Three recent randomized, double-blind, placebo-controlled trials investigated the effect of vitamin D repletion on functional capacity (i.e., cardiopulmonary stress testing, $6 \mathrm{MWD}$, isokinetic muscle testing) in HF patients with vitamin D deficiency. The results did not show an improvement in physical performance, despite a significant increase in plasmatic vitamin $\mathrm{D}$ levels and a reduction in aldosterone concentration [68-70]. A randomized trial is ongoing to investigate the impact of long-term vitamin $\mathrm{D}$ daily administration regarding $6 \mathrm{MWD}$, left ventricular function at cardiac magnetic resonance, cardiopulmonary exercise testing and biochemical changes (VitamIN D treating patIents with Chronic heArT failurE, VINDICATE, NCT01619891). Another ongoing randomized double-blind placebo-controlled trial is recruiting HF patients with low vitamin D levels to demonstrate whether its replacement could improve long-term prognosis when added to standard of care therapy (Vitamin D and Mortality in Heart Failure, EVITA, NCT01326650).

In conclusion, vitamin D supplementation may be a good target to improve frailty, fatigue and functional decline in patients with HF, but more data are necessary to recommend it for HF patients.

\section{Iron}

Iron is a key element in the human metabolism, it is involved as an enzyme in oxygen transport and storage, and it is involved in the oxidative metabolism in the heart and skeletal muscles [71]. Iron deficiency is the most common nutritional disorder, affecting one-third of the general population all over the world and determining premature death [72-74]. Iron deficiency contributes to cardiac and peripheral dysfunction and is associated with increased risk of death, independent of the hemoglobin level [75]. Iron deficiency affects nearly $40 \%$ of HF patients and it is associated with a proinflammatory state which impairs the intestinal absorption of iron itself [71]. In HF patients, iron deficiency can be defined as ferritin $<100 \mathrm{mg} / \mathrm{L}$ (absolute iron deficiency, related to depletion of iron stores), or $100-300 \mathrm{mg} / \mathrm{L}$ with transferrin saturation $<20 \%$ (functional iron deficiency, related to systemic inflammation). Jankowska et al. demonstrated that iron deficiency is a strong and independent predictor of prognosis in $\mathrm{HF}$, with a 1.58 increased risk of death or heart transplant, suggesting a possible therapeutic role of iron implementation [34]. Indeed, several trials have demonstrated that repletion of iron deficiency improves symptoms, exercise capacity and quality of life in HF patients [76-79]. The EFFECT-HF trial (Effect of Ferric Carboxymaltose on Exercise Capacity in Patients with Iron Deficiency and Chronic Heart Failure) is currently recruiting patients to analyze the role of ferric carboxymaltose on peak VO2 (NCT01394562). Recently, the CONFIRM-HF trial (Double-Blind, Randomized, Placebo-Controlled Study to Assess the Effects of Intravenous Ferric Carboxymaltose on Functional Capacity in Patients with Chronic Heart Failure and Iron Deficiency) demonstrated a $61 \%$ relative decrease in HF hospitalization for worsening HF and an improvement in functional capacity, symptoms, and quality of life in patients receiving intravenous ferric carboxymaltose [80]. A meta-analysis of five randomized clinical trials suggested that intravenous iron supplementation reduces cardiovascular hospitalization (OR 0.44), cardiovascular death or hospitalization for worsening HF (OR 0.39), while improving quality of life, functional capacity and other symptoms [36]. On the 
other hand, excessive iron supplementation may lead to tissue deposition and to free radical tissue damage, so mortality-driven studies about intravenous iron are still needed to assess long-term safety. However, the current European Society of Cardiology (ESC) guidelines on the management of HF recommend searching for reversible causes of $\mathrm{HF}$ and comorbidities and suggest that iron therapy can be considered as a treatment in patients with iron deficiency [1].

\section{Thiamine}

Thiamine is one of the first compounds recognized as a vitamin, known as vitamin B1. Thiamine acts as a coenzyme for oxidation-reduction reactions in the glucose metabolism and in the citric acid cycle, and as a coenzyme in the reactions catalyzed by the enzyme pyruvate dehydrogenase [81]. The active form thiamine pyrophosphate (TPP) is involved in bioenergetics ATP synthesis processes, hemoglobin production, $\gamma$-aminobutyric acid (GABA) synthesis, immunity stress response, and gene expression [82]. Thiamine deficiency can be associated with alcoholism, hemodialysis, poor nutrition, cancer, pregnancy, bariatric surgery, and Alzheimer's disease [83]. Beriberi syndrome is a disease caused by a vitamin B1 (thiamine) deficiency [84]. There are two types of this syndrome: wet beriberi and dry beriberi. Wet beriberi affects the heart and circulatory system. Dry beriberi damages the nerves and can lead to a loss of muscle strength and finally muscle paralysis. When the cardiovascular involvement is predominant ("wet" beriberi), patients present biventricular dysfunction, vasodilatation, tachycardia and fluid retention [85]. In Western countries this syndrome is quite rare and mainly related to alcoholism and malnutrition and/or malabsorption. However, a subclinical thiamine deficiency is common in HF patients with long-term furosemide intake, elevated basal metabolic rate, malnutrition and advanced age [86,87]. According to Hanninen et al., about one-third of hospitalized patients affected by chronic HF showed a thiamine deficiency and even small doses of supplementation ( $1.5 \mathrm{mg} /$ day) may be effective in reducing this deficiency [88]. Only two small randomized placebo-controlled trials demonstrated that thiamin administration in HF patients improves LVEF, diuresis, natriuresis and quality of life [89,90].

A randomized trial conducted in patients with AHF did not show an improvement in dyspnea $4 \mathrm{~h}$ after thiamine administration, or on hospitalization rate and duration of hospital stay [91]. Two recent systematic reviews and meta-analysis confirmed the beneficial effect on LVEF [92,93].

Nevertheless, no studies to date were considerable enough to prove a prognostic role of thiamine deficiency correction in HF. In conclusion, thiamine supplementation has beneficial effects on cardiac function in HF patients, but larger studies are needed to test its prognostic significance.

\section{Creatine}

Creatine is an important energetic molecule in skeletal muscles and the heart; it is able to store and transfer high-energy phosphate. Creatine is synthesized from arginine, glycine, and methionine in the kidneys, liver, and pancreas [94]. In healthy people, the dietary supplement of creatine (about $20 \mathrm{~g} /$ day for five days or about $2 \mathrm{~g} /$ day for 30 days) results in increased skeletal muscle creatine and phosphocreatine [95]. In HF its concentration is reduced, probably as a consequence of increased sympathetic activity [96]. Gordon et al. demonstrated that oral supplementation of $20 \mathrm{~g}$ creatine daily for 10 days in 17 patients with chronic HF did not improve LVEF but increased skeletal muscle energy-rich phosphagens and performance as regards both strength and endurance [97]. Few studies have evaluated the role of its supplementation in HF patients, demonstrating possible beneficial effects regarding exercise capacity, muscle strength and metabolism [98-100]. No data are available about its prognostic significance if added to standard-of-care therapy.

\section{Amino Acids}

Amino acids (AAs) are fundamental compounds of proteins and their metabolism represents a complex process involving a large number of fundamental metabolites, which are found in vitamins, dietary proteins and nutritional supplements [101]. AAs' availability is reduced in HF and such patients 
develop a hypercatabolic state that results in cardiac cachexia [102,103]. HF patients' AAs are highly metabolized by skeletal muscles even at rest [104]. During the hypercatabolic state, muscle proteins are degraded and AAs are released, leading to a progressive loss in muscle volume. AA deficiency changes the cardiac structure with a transition from the "red fibers" that are more efficient in energy utilization to the "white fibers" that are less efficient [105]. Mixed AA administration has been demonstrated to improve myocardial performance and it stimulates protein synthesis itself [106,107]. Several studies have evaluated the effects of AA single supplementation in HF patients.

\subsection{Taurine}

Taurine is a semi-essential non-codified AA, resulting from cysteic acid decarboxylation. It is expressed at high levels in the myocytes, but its function has not been completely clarified yet [108]. Taurine has antioxidant properties, and regulates the phosphorylation of two myocardial key proteins in excitation-contraction coupling, phospholamban and sarcoplasmatic reticular Ca2+ ATPase (SERCA2), and it also contributes to the function of mitochondria enzymes [109-111]. The taurine-deficient heart has an impaired aerobic metabolism and its deficiency is associated with a reduction in oxygen consumption, an elevation in glycolysis and lactate concentration and a decline in ATP activity. Similar mitochondrial functional alterations can be observed in MELAS disease (mitochondrial myopathy, encephalopathy, lactic acidosis and stroke-like episodes) and MERRF syndrome (myoclonic epilepsy and ragged-red fiber syndrome) [112,113]. Taurine may prevent HF progression, reducing cardiotoxicity induced by detrimental activation of the sympathetic nervous system and angiotensin II [114]. Some studies in humans have demonstrated a beneficial effect of taurine supplementation in HF patients. They found that a few weeks of therapy improved exercise capacity, LVEF and NYHA class [115-117]. Consequently, in Japan taurine supplementation is approved for the treatment of HF. Nevertheless, to date, a clear association with mortality outcomes has not been demonstrated yet.

\subsection{Carnitine}

L-carnitine is a non-proteic, non-essential AA acting as a cofactor in fatty acid transport into mitochondria, acetyl-CoA production and glucose metabolism [118,119]. L-carnitine supplementation improves cardiac metabolic and left ventricular (LV) function and also has a protective effect on the ischemic myocardium, preventing fatty acid ester accumulation that occurs during acute ischemic episodes [120]. In HF patients, L-carnitine levels are reduced up to 50\% [119]. The supplementation of proprionyl-L-carnitine to such patients has been largely studied, even in a double-blind placebo-controlled study. Overall, they demonstrated an improvement only in exercise capacity and in LV volumes [121-124]. According to Ferrari et al., these achievements occur without major modifications in the hemodynamic and neurohormonal state, but they are principally related to improved skeletal muscle metabolism [125,126]. To test the prognostic impact of carnitine supplementation in HF, Rizos conducted a double-blind placebo-controlled trial with 2 g/day vs. placebo administration and found an improvement in three-year survival [37].

\subsection{Arginine}

Arginine is a semi-essential AA involved in creatine synthesis. It is also the substrate of nitric oxide (NO) synthase which produces NO, leading to vasodilation and restoring endothelial function [127]. Some studies tested the role of arginine supplementation in HF. They found an improvement in endothelial-dependent vasodilation, muscular blood flow during exercise, functional capacity and exercise duration [128-130]. No data are available about survival outcomes in HF patients.

\subsection{Mixtures of $A A s$}

AA supplementation has been recently encouraged due to the possible beneficial effects on both the myocardium and skeletal muscle [112]. Aquilani et al. showed that 30-day oral administration of a 
mixture of $8 \mathrm{~g}$ /day AAs to elderly HF outpatients, in a double-blind fashion, improves exercise capacity measured by the cardiopulmonary exercise test (i.e., increased work, longer duration, more intense oxidative metabolism) and NYHA class. In addition, they found an improvement in post-exercise VO2 [131]. They concluded that AAs might positively affect circulatory function, muscle oxygen consumption, aerobic metabolism and recovery after exercise. Similar results have been obtained by Scognamiglio et al. and by our group after a three-month therapy with a wider mixture of AAs administered at $8 \mathrm{~g} /$ day $[132,133]$. Nevertheless, no studies have yet investigated their role in improving survival in HF patients.

\section{Carnosine}

L-carnosine is a dipeptide ( $\beta$-alanine-L-histidine) present at high concentrations in the myocardium, skeletal muscles and brain [134]. It has anti-aging, antioxidant and immune-modulating properties, favoring NO production in the endothelial cells [135-137]. Recently, cardiometabolic proprieties of carnosine have raised an interest in clinical research [138]. Recent data suggest that carnosine supplementation may be effective in the prevention of type 2 diabetes in obese patients [139]. Our group has demonstrated that L-carnosine, added to conventional therapy, has beneficial effects on exercise performance and quality of life in stable, chronic HF [140]. Further data are necessary to evaluate its effects on LVEF and prognosis in chronic HF.

\section{Multiple Micronutrient Supplementation}

The approach of supplementing HF patients with multiple micronutrients is compelling. Theoretically, it may warrant the correction of several deficiencies, thus improving multiple metabolic pathways. Witte et al. analyzed the effect of a combination of 10 different micronutrients on LV function and quality of life in 30 elderly patients with stable systolic HF due to ischemic heart disease compared to controls [141]. This study suggested that a long-term multiple micronutrient supplementation can improve quality of life and LVEF in patients with HF [142]. A subsequent randomized, placebo-controlled study was conducted on 74 patients with chronic HF with a mixture of several micronutrients, including mainly vitamins and minerals (not AAs). Despite showing an increase of serum concentration of the supplemented micronutrients, no benefits in the change of LVEF, quality of life, natriuretic peptides and inflammatory marker levels were recorded [142]. In spite of the disappointing results of this study, further research is necessary to definitely clarify the best composition and the possible role of micronutrient supplementation in HF.

\section{Conclusions}

Micronutrients may act synergistically with traditional therapies in patients with HF, improving energetic metabolism and energy transfer. Despite plenty of small evidence, large clinical trials are still lacking. In addition, to date, only a few small studies have evaluated a multiple micronutrient approach to overcome the limitations with a single-supplement method. Future research is needed to address these important questions.

Acknowledgments: We thank CVie Therapeutics Limited for a donation to the University of Brescia.

Author Contributions: Sciatti E. drafted the manuscript; Ravera, A., Vizzardi, E., Bonadei, I., Carubelli, V., Gorga, E. collected data; Lombardi, C., Metra, M. revised and approved the manuscript.

Conflicts of Interest: V.C. received a research grant from CVie Therapeutics Limited and consulting honoraria from Servier. M.M. has served as a consultant for Bayer, Novartis, Servier, and Trevena. All other authors have nothing to disclose. All the aforementioned conflicts of interest have no relationship with the submitted article. 


\section{Abbreviations}

$\begin{array}{ll}\text { AAs } & \text { amino acids } \\ \text { ARBs } & \text { angiotensin receptor blockers } \\ \text { AHF } & \text { Acute heart failure } \\ \text { ATP } & \text { adenosine triphosphate } \\ \text { CoQ10 } & \text { coenzyme Q10 } \\ \text { GABA } & \gamma \text {-aminobutyric acid } \\ \text { HF } & \text { heart failure } \\ \text { HFrEF } & \text { heart failure with reduced ejection fraction } \\ \text { HFpEF } & \text { heart failure with preserved ejection fraction } \\ \text { NYHA } & \text { New York Heart Association } \\ \text { MACE } & \text { major adverse cardiovascular events } \\ \text { LVEF } & \text { left ventricular ejection fraction } \\ \text { NO } & \text { nitric oxide } \\ \text { TPP } & \text { thiamine pyrophosphate } \\ 6 M W D & \text { 6-minute walking distance }\end{array}$

\section{References}

1. Ponikowski, P.; Voors, A.A.; Anker, S.D.; Bueno, H.; Cleland, J.G.; Coats, A.J.; Falk, V.; González-Juanatey, J.R.; Harjola, V.P.; Jankowska, E.A.; et al. 2016 ESC Guidelines for the diagnosis and treatment of acute and chronic heart failure: The Task Force for the diagnosis and treatment of acute and chronic heart failure of the European Society of Cardiology (ESC) Developed with the special contribution of the Heart Failure Association (HFA) of the ESC. Eur. Heart J. 2016. [CrossRef]

2. Mentz, R.J.; Felker, G.M. Noncardiac comorbidities and acute heart failure patients. Heart Fail. Clin. 2013, 9, 359-367. [CrossRef] [PubMed]

3. Metra, M.; Bugatti, S.; Bettari, L.; Carubelli, V.; Danesi, R.; Lazzarini, V.; Lombardi, C.; Cas, L.D. Can we improve the treatment of congestion in heart failure? Expert Opin. Pharmacother. 2011, 12, 1369-1379. [CrossRef] [PubMed]

4. Pang, P.S.; Komajda, M.; Gheorghiade, M. The current and future management of acute heart failure syndromes. Eur. Heart J. 2010, 31, 784-793. [CrossRef] [PubMed]

5. Metra, M.; Bettari, L.; Carubelli, V.; Bugatti, S.; Dei Cas, A.; Del Magro, F.; Lazzarini, V.; Lombardi, C.; Dei Cas, L. Use of inotropic agents in patients with advanced heart failure: Lessons from recent trials and hopes for new agents. Drugs 2011, 71, 515-525. [CrossRef] [PubMed]

6. Arcand, J.; Floras, V.; Ahmed, M.; Al-Hesayen, A.; Ivanov, J.; Allard, J.P.; Newton, G.E. Nutritional inadequacies in patients with stable heart failure. J. Am. Diet. Assoc. 2009, 109, 1909-1913. [CrossRef] [PubMed]

7. Aquilani, R.; Opasich, C.; Verri, M.; Boschi, F.; Febo, O.; Pasini, E.; Pastoris, O. Is nutritional intake adequate in chronic heart failure patients? J. Am. Coll. Cardiol. 2003, 42, 1218-1223. [CrossRef]

8. Catapano, G.; Pedone, C.; Nunziata, E.; Zizzo, A.; Passantino, A.; Incalzi, R.A. Nutrient intake and serum cytokine pattern in elderly people with heart failure. Eur. J. Heart Fail. 2008, 10, 428-434. [CrossRef] [PubMed]

9. Son, Y.J.; Song, E.K. High nutritional risk is associated with worse health-related quality of life in patients with heart failure beyond sodium intake. Eur. J. Cardiovasc. Nurs. 2013, 12, 184-192. [CrossRef] [PubMed]

10. Soukoulis, V.; Dihu, J.B.; Sole, M.; Anker, S.D.; Cleland, J.; Fonarow, G.C.; Metra, M.; Pasini, E.; Strzelczyk, T.; Taegtmeyer, H.; et al. Micronutrient deficiencies an unmet need in heart failure. J. Am. Coll. Cardiol. 2009, 54, 1660-1673. [CrossRef] [PubMed]

11. Yancy, C.W.; Jessup, M.; Bozkurt, B.; Butler, J.; Casey, D.E., Jr.; Drazner, M.H.; Fonarow, G.C.; Geraci, S.A.; Horwich, T.; Januzzi, J.L.; et al. 2013 ACCF/AHA guideline for the management of heart failure: Executive summary: A report of the American College of Cardiology Foundation/American Heart Association Task Force on practice guidelines. Circulation 2013, 128, 1810-1852. [CrossRef] [PubMed]

12. Doenst, T.; Abel, E.D. Spotlight on metabolic remodelling in heart failure. Cardiovasc. Res. 2011, 90, $191-193$. [CrossRef] [PubMed]

13. Ventura-Clapier, R.; Garnier, A.; Veksler, V. Energy metabolism in heart failure. J. Physiol. 2004, 555, 1-13. [CrossRef] [PubMed] 
14. Stanley, W.C.; Recchia, F.A.; Lopaschuk, G.D. Myocardial substrate metabolism in the normal and failing heart. Physiol. Rev. 2005, 85, 1093-1129. [CrossRef] [PubMed]

15. Ingwall, J.S.; Weiss, R.G. Is the failing heart energy starved? On using chemical energy to support cardiac function. Circ. Res. 2004, 95, 135-145. [CrossRef] [PubMed]

16. Neubauer, S. The failing heart-An engine out of fuel. N. Engl. J. Med. 2007, 356, 1140-1151. [CrossRef] [PubMed]

17. Neubauer, S.; Horn, M.; Cramer, M.; Harre, K.; Newell, J.B.; Peters, W.; Pabst, T.; Ertl, G.; Hahn, D.; Ingwall, J.S.; et al. Myocardial phosphocreatine-to-ATP ratio is a predictor of mortality in patients with dilated cardiomyopathy. Circulation 1997, 96, 2190-2196. [CrossRef] [PubMed]

18. Van Bilsen, M.; van Nieuwenhoven, F.A.; van der Vusse, G.J. Metabolic remodelling of the failing heart: Beneficial or detrimental? Cardiovasc. Res. 2009, 81, 420-428. [CrossRef] [PubMed]

19. Van Bilsen, M.; Smeets, P.J.; Gilde, A.J.; van der Vusse, G.J. Metabolic remodelling of the failing heart: The cardiac burn-out syndrome? Cardiovasc. Res. 2004, 61, 218-226. [CrossRef] [PubMed]

20. Gupta, A.; Akki, A.; Wang, Y.; Leppo, M.K.; Chacko, V.P.; Foster, D.B.; Caceres, V.; Shi, S.; Kirk, J.A.; Su, J.; et al. Creatine kinase-mediated improvement of function in failing mouse hearts provides causal evidence the failing heart is energy starved. J. Clin. Investig. 2012, 122, 291-302. [CrossRef] [PubMed]

21. Sole, M.J.; Jeejeebhoy, K.N. Conditioned nutritional requirements and the pathogenesis and treatment of myocardial failure. Curr. Opin. Clin. Nutr. Metab. Care 2000, 3, 417-424. [CrossRef] [PubMed]

22. Zhang, M.; Shah, A.M. Role of reactive oxygen species in myocardial remodeling. Curr. Heart Fail. Rep. 2007, 4, 26-30. [CrossRef] [PubMed]

23. Krim, S.R.; Campbell, P.; Lavie, C.J.; Ventura, H. Micronutrients in chronic heart failure. Curr. Heart Fail. Rep. 2013, 10, 46-53. [CrossRef] [PubMed]

24. Allard, M.L.; Jeejeebhoy, K.N.; Sole, M.J. The management of conditioned nutritional requirements in heart failure. Heart Fail. Rev. 2006, 11, 75-82. [CrossRef] [PubMed]

25. Witte, K.K.; Clark, A.L.; Cleland, J.G. Chronic heart failure and micronutrients. J. Am. Coll. Cardiol. 2001, 37, 1765-1774. [CrossRef]

26. Anker, S.D.; Steinborn, W.; Strassburg, S. Cardiac cachexia. Ann. Med. 2004, 36, 518-529. [CrossRef] [PubMed]

27. Anker, S.D.; Morley, J.E. Cachexia: A nutritional syndrome? J. Cachexia Sarcopenia Muscle 2015, 6, $269-271$. [CrossRef] [PubMed]

28. Anker, S.D.; Ponikowski, P.; Varney, S.; Chua, T.P.; Clark, A.L.; Webb-Peploe, K.M.; Harrington, D.; Kox, W.J.; Poole-Wilson, P.A.; Coats, A.J. Wasting as independent risk factor for mortality in chronic heart failure. Lancet 1997, 349, 1050-1053. [CrossRef]

29. Von Haehling, S.; Morley, J.E.; Anker, S.D. From muscle wasting to sarcopenia and myopenia: Update 2012. J. Cachexia Sarcopenia Muscle 2012, 3, 213-217. [CrossRef] [PubMed]

30. Alsafwah, S.; Laguardia, S.P.; Arroyo, M.; Dockery, B.K.; Bhattacharya, S.K.; Ahokas, R.A.; Newman, K.P. Congestive heart failure is a systemic illness: A role for minerals and micronutrients. Clin. Med. Res. 2007, 5, 238-243. [CrossRef] [PubMed]

31. Molyneux, S.L.; Florkowski, C.M.; George, P.M.; Pilbrow, A.P.; Frampton, C.M.; Lever, M.; Richards, A.M. Coenzyme Q10: An independent predictor of mortality in chronic heart failure. J. Am. Coll. Cardiol. 2008, 52, 1435-1441. [CrossRef] [PubMed]

32. McMurray, J.J.; Dunselman, P.; Wedel, H.; Cleland, J.G.; Lindberg, M.; Hjalmarson, A.; Kjekshus, J.; Waagstein, F.; Apetrei, E.; Barrios, V.; et al. Coenzyme Q10, rosuvastatin, and clinical outcomes in heart failure: A pre-specified substudy of CORONA (controlled rosuvastatin multinational study in heart failure). J. Am. Coll. Cardiol. 2010, 56, 1196-1204. [CrossRef] [PubMed]

33. Liu, L.C.; Voors, A.A.; van Veldhuisen, D.J.; van der Veer, E.; Belonje, A.M.; Szymanski, M.K.; Silljé, H.H.; van Gilst, W.H.; Jaarsma, T.; de Boer, R.A. Vitamin D status and outcomes in heart failure patients. Eur. J. Heart Fail. 2011, 13, 619-625. [CrossRef] [PubMed]

34. Jankowska, E.A.; Rozentryt, P.; Witkowska, A.; Nowak, J.; Hartmann, O.; Ponikowska, B.; Borodulin-Nadzieja, L.; Banasiak, W.; Polonski, L.; Filippatos, G.; et al. Iron deficiency: An ominous sign in patients with systolic chronic heart failure. Eur. Heart J. 2010, 31, 1872-1880. [CrossRef] [PubMed] 
35. Mortensen, S.A.; Rosenfeldt, F.; Kumar, A.; Dolliner, P.; Filipiak, K.J.; Pella, D.; Alehagen, U.; Steurer, G.; Littarru, G.P. Q-SYMBIO Study Investigators. The effect of coenzyme Q10 on morbidity and mortality in chronic heart failure: Results from Q-SYMBIO: A randomized double-blind trial. JACC Heart Fail. 2014, 2, 641-649. [CrossRef] [PubMed]

36. Jankowska, E.A.; Tkaczyszyn, M.; Suchocki, T.; Drozd, M.; von Haehling, S.; Doehner, W.; Banasiak, W.; Filippatos, G.; Anker, S.D.; Ponikowski, P.; et al. Effects of intravenous iron therapy in iron-deficient patients with systolic heart failure: A meta-analysis of randomized controlled trials. Eur. J. Heart Fail. 2016. [CrossRef] [PubMed]

37. Rizos, I. Three-year survival of patients with heart failure caused by dilated cardiomyopathy and L-carnitine administration. Am. Heart J. 2000, 139, S120-S123. [CrossRef] [PubMed]

38. Sharma, A.; Fonarow, G.C.; Butler, J.; Ezekowitz, J.A.; Felker, G.M. Coenzyme Q10 and Heart Failure: A State-of-the-Art Review. Circ. Heart Fail. 2016. [CrossRef] [PubMed]

39. Sarma, S.; Gheorghiade, M. Nutritional assessment and support of the patient with acute heart failure. Curr. Opin. Crit. Care 2010, 16, 413-418. [CrossRef] [PubMed]

40. Freeman, L.M.; Roubenoff, R. The nutrition implications of cardiac cachexia. Nutr. Rev. 1994, 52, 340-347. [CrossRef] [PubMed]

41. Folkers, K.; Langsjoen, P.; Willis, R.; Richardson, P.; Xia, L.J.; Ye, C.Q.; Tamagawa, H. Lovastatin decreases coenzyme Q levels in humans. Proc. Natl. Acad. Sci. USA 1990, 87, 8931-8934. [CrossRef] [PubMed]

42. Berthold, H.K.; Naini, A.; Di Mauro, S.; Hallikainen, M.; Gylling, H.; Krone, W.; Gouni-Berthold, I. Effect of ezetimibe and/or simvastatin on coenzyme Q10 levels in plasma: A randomised trial. Drug Saf. 2006, 29, 703-712. [CrossRef] [PubMed]

43. Kishi, T.; Watanabe, T.; Folkers, K. Bioenergetics in clinical medicine XV. Inhibition of coenzyme Q10-enzymes by clinically used adrenergic blockers of beta-receptors. Res. Commun. Chem. Pathol. Pharmacol. 1977, 17, 157-164. [PubMed]

44. Morisco, C.; Trimarco, B.; Condorelli, M. Effect of CoQ10 therapy in patients with congestive heart failure: A long-term multicenter randomized study. Clin. Investig. 1993, 71, 134S-136S. [CrossRef]

45. Fotino, A.D.; Thompson-Paul, A.M.; Bazzano, L.A. Effect of coenzyme Q10 supplementation on heart failure: A meta-analysis. Am. J. Clin. Nutr. 2013, 97, 268-275. [CrossRef] [PubMed]

46. Bhagavan, H.N.; Chopra, R.K. Plasma coenzyme Q10 response to oral ingestion of coenzyme Q10 formulations. Mitochondrion 2007, 7, S78-S88. [CrossRef] [PubMed]

47. Berman, M.; Erman, A.; Ben-Gal, T.; Dvir, D.; Georghiou, G.P.; Stamler, A.; Vered, Y.; Vidne, B.A.; Aravot, D. Coenzyme Q10 in patients with end-stage heart failure awaiting cardiac transplantation: A randomized, placebo-controlled study. Clin. Cardiol. 2004, 27, 295-299. [CrossRef] [PubMed]

48. Hofman-Bang, C.; Rehnqvist, N.; Swedberg, K.; Wiklund, I.; Aström, H. Coenzyme Q10 as an adjunctive in the treatment of chronic congestive heart failure. The Q10 Study Group. J. Card. Fail. 1995, 1, 101-107. [CrossRef]

49. Keogh, A.; Fenton, S.; Leslie, C.; Aboyoun, C.; Macdonald, P.; Zhao, Y.C.; Bailey, M.; Rosenfeldt, F. Randomised double-blind, placebo-controlled trial of coenzyme Q10 therapy in class II and III systolic heart failure. Heart Lung Circ. 2003, 12, 135-141. [CrossRef] [PubMed]

50. Madmani, M.E.; Yusuf Solaiman, A.; Tamr Agha, K.; Madmani, Y.; Shahrour, Y.; Essali, A.; Kadro, W. Coenzyme Q10 for Heart Failure. Cochrane Database System Revew; John Wiley \& Sons Ltd.: London, UK, 2014.

51. Krüger, C.; Erdmann, E.; Näbauer, M.; Beuckelmann, D.J. Intracellular calcium handling in isolated ventricular myocytes from cardiomyopathic hamsters (strain BIO 14.6) with congestive heart failure. Cell Calcium 1994, 16, 500-508.

52. Somjen, D.; Weisman, Y.; Kohen, F.; Gayer, B.; Limor, R.; Sharon, O.; Jaccard, N.; Knoll, E.; Stern, N. 25-hydroxyvitaminD3-1alpha-hydroxylase is expressed in human vascular smooth muscle cells and is upregulated by parathyroid hormone and estrogenic compounds. Circulation 2005, 111, 1666-16671. [CrossRef] [PubMed]

53. Simpson, R.U.; Weishaar, R.E. Involvement of 1,25-dihydroxyvitamin D3 in regulating myocardial calcium metabolism: Physiological and pathological actions. Cell Calcium 1988, 9, 285-292. [CrossRef]

54. Weishaar, R.E.; Simpson, R.U. Involvement of vitamin D3 with cardiovascular function. II. Direct and indirect effects. Am. J. Physiol. 1987, 253, E675-E683. [PubMed] 
55. Wu, J.; Garami, M.; Cao, L.; Li, Q.; Gardner, D.G. 1,25(OH)2D3 suppresses expression and secretion of atrial natriuretic peptide from cardiac myocytes. Am. J. Physiol. 1995, 268, E1108-E1113. [PubMed]

56. Boxer, R.S.; Hoit, B.D.; Schmotzer, B.J.; Stefano, G.T.; Gomes, A.; Negrea, L. The effect of vitamin d on aldosterone and health status in patients with heart failure. J. Card. Fail. 2014, 20, 334-342. [CrossRef] [PubMed]

57. Meems, L.M.; van der Harst, P.; van Gilst, W.H.; de Boer, R.A. Vitamin D biology in heart failure: Molecular mechanisms and systematic review. Curr. Drug Targets 2011, 12, 29-41. [CrossRef] [PubMed]

58. Judd, S.E.; Tangpricha, V. Vitamin D deficiency and risk for cardiovascular disease. Am. J. Med. Sci. 2009, 338, 40-44. [CrossRef] [PubMed]

59. Brewer, L.C.; Michos, E.D.; Reis, J.P. Vitamin D in atherosclerosis, vascular disease, and endothelial function. Curr. Drug Targets 2011, 12, 54-60. [CrossRef] [PubMed]

60. Zittermann, A.; Schleithoff, S.S.; Tenderich, G.; Berthold, H.K.; Körfer, R.; Stehle, P. Low vitamin D status: A contributing factor in the pathogenesis of congestive heart failure? J. Am. Coll. Cardiol. 2003, 41, 105-112. [CrossRef]

61. Patel, R.; Rizvi, A.A. Vitamin D deficiency in patients with congestive heart failure: Mechanisms, manifestations, and management. South Med. J. 2011, 104, 325-330. [CrossRef] [PubMed]

62. Lazzarini, V.; Bettari, L.; Bugatti, S.; Carubelli, V.; Lombardi, C.; Metra, M.; Dei Cas, L. Can we prevent or treat renal dysfunction in acute heart failure? Heart Fail. Rev. 2012, 17, 291-303. [CrossRef] [PubMed]

63. Rauchhaus, M.; Doehner, W.; Francis, D.P.; Davos, C.; Kemp, M.; Liebenthal, C.; Niebauer, J.; Hooper, J.; Volk, H.D.; Coats, A.J.; et al. Plasma cytokine parameters and mortality in patients with chronic heart failure. Circulation 2000, 102, 3060-3067. [CrossRef] [PubMed]

64. Haug, C.J.; Aukrust, P.; Haug, E.; Mørkrid, L.; Müller, F.; Frøland, S.S. Severe deficiency of 1,25-dihydroxyvitamin D3 in human immunodeficiency virus infection: Association with immunological hyperactivity and only minor changes in calcium homeostasis. J. Clin. Endocrinol. Metab. 1998, 83, 3832-3838. [CrossRef] [PubMed]

65. Resnick, L.M.; Müller, F.B.; Laragh, J.H. Calcium-regulating hormones in essential hypertension. Relation to plasma renin activity and sodium metabolism. Ann. Int. Med. 1986, 105, 649-654. [CrossRef] [PubMed]

66. Boxer, R.S.; Dauser, D.A.; Walsh, S.J.; Hager, W.D.; Kenny, A.M. The association between vitamin D and inflammation with the 6-minute walk and frailty in patients with heart failure. J. Am. Geriatr. Soc. 2008, 56, 454-461. [CrossRef] [PubMed]

67. Pilz, S.; Henry, R.M.; Snijder, M.B.; van Dam, R.M.; Nijpels, G.; Stehouwer, C.D.; Kamp, O.; Tomaschitz, A.; Pieber, T.R.; Dekker, J.M. Vitamin D deficiency and myocardial structure and function in older men and women: The Hoorn study. J. Endocrinol. Investig. 2010, 33, 612-617. [CrossRef] [PubMed]

68. Schleithoff, S.S.; Zittermann, A.; Tenderich, G.; Berthold, H.K.; Stehle, P.; Koerfer, R. Vitamin D supplementation improves cytokine profiles in patients with congestive heart failure: A double-blind, randomized, placebo-controlled trial. Am. J. Clin. Nutr. 2006, 83, 754-759. [PubMed]

69. Witham, M.D.; Crighton, L.J.; Gillespie, N.D.; Struthers, A.D.; McMurdo, M.E. The effects of vitamin D supplementation on physical function and quality of life in older patients with heart failure: A randomized controlled trial. Circ. Heart Fail. 2010, 3, 195-201. [CrossRef] [PubMed]

70. Boxer, R.S.; Kenny, A.M.; Schmotzer, B.J.; Vest, M.; Fiutem, J.J.; Piña, I.L. A randomized controlled trial of high dose vitamin D3 in patients with heart failure. JACC Heart Fail. 2013, 1, 84-90. [CrossRef] [PubMed]

71. Cohen-Solal, A.; Leclercq, C.; Deray, G.; Lasocki, S.; Zambrowski, J.J.; Mebazaa, A.; de Groote, P.; Damy, T.; Galinier, M. Iron deficiency: An emerging therapeutic target in heart failure. Heart 2014, 100, 1414-1420. [CrossRef] [PubMed]

72. Zimmermann, M.B.; Hurrell, R.F. Nutritional iron deficiency. Lancet 2007, 370, 511-520. [CrossRef]

73. Andrews, N.C. Disorders of iron metabolism. N. Engl. J. Med. 1999, 341, 1986-1995. [CrossRef] [PubMed]

74. Clark, S.F. Iron deficiency anemia: Diagnosis and management. Curr. Opin. Gastroenterol. 2009, 25, $122-128$. [CrossRef] [PubMed]

75. Von Haehling, S.; Jankowska, E.A.; van Veldhuisen, D.J.; Ponikowski, P.; Anker, S.D. Iron deficiency and cardiovascular disease. Nat. Rev. Cardiol. 2015, 12, 659-669. [CrossRef] [PubMed]

76. Anker, S.D.; Comin Colet, J.; Filippatos, G.; Willenheimer, R.; Dickstein, K.; Drexler, H.; Lüscher, T.F.; Bart, B.; Banasiak, W.; Niegowska, J.; et al. Ferric carboxymaltose in patients with heart failure and iron deficiency. N. Engl. J. Med. 2009, 361, 2436-2448. [CrossRef] [PubMed] 
77. Toblli, J.E.; Lombraña, A.; Duarte, P.; Di Gennaro, F. Intravenous iron reduces NT-pro-brain natriuretic peptide in anemic patients with chronic heart failure and renal insufficiency. J. Am. Coll. Cardiol. 2007, 50, 1657-1665. [CrossRef] [PubMed]

78. Bolger, A.P.; Bartlett, F.R.; Penston, H.S.; O’Leary, J.; Pollock, N.; Kaprielian, R.; Chapman, C.M. Intravenous iron alone for the treatment of anemia in patients with chronic heart failure. J. Am. Coll. Cardiol. 2006, 48, 1225-1227. [CrossRef] [PubMed]

79. Okonko, D.O.; Grzeslo, A.; Witkowski, T.; Mandal, A.K.; Slater, R.M.; Roughton, M.; Foldes, G.; Thum, T.; Majda, J.; Banasiak, W.; et al. Effect of intravenous iron sucrose on exercise tolerance in anemic and nonanemic patients with symptomatic chronic heart failure and iron deficiency FERRIC-HF: A randomized, controlled, observer-blinded trial. J. Am. Coll. Cardiol. 2008, 51, 103-112. [CrossRef] [PubMed]

80. Ponikowski, P.; van Veldhuisen, D.J.; Comin-Colet, J.; Ertl, G.; Komajda, M.; Mareev, V.; McDonagh, T.; Parkhomenko, A.; Tavazzi, L.; Levesque, V.; et al. Beneficial effects of long-term intravenous iron therapy with ferric carboxymaltose in patients with symptomatic heart failure and iron deficiency. Eur. Heart J. 2015, 36, 657-668. [CrossRef] [PubMed]

81. DiNicolantonio, J.J.; Niazi, A.K.; Lavie, C.J.; O'Keefe, J.H.; Ventura, H.O. Thiamine supplementation for the treatment of heart failure: A review of the literature. Congest Heart Fail. 2013, 19, 214-222. [CrossRef] [PubMed]

82. Roman-Campos, D.; Cruz, J.S. Current aspects of thiamine deficiency on heart function. Life Sci. 2014, 98, 1-5. [CrossRef] [PubMed]

83. Manzanares, W.; Hardy, G. Thiamine supplementation in the critically ill. Curr. Opin. Clin. Nutr. Metab. Care 2011, 14, 610-617. [CrossRef] [PubMed]

84. Wooley, J.A. Characteristics of thiamin and its relevance to the management of heart failure. Nutr. Clin. Pract. 2008, 23, 487-493. [CrossRef] [PubMed]

85. Rao, S.N.; Chandak, G.R. Cardiac beriberi: Often a missed diagnosis. J. Trop. Pediatr. 2010, 56, $284-285$. [CrossRef] [PubMed]

86. Yui, Y.; Itokawa, Y.; Kawai, C. Furosemide-induced thiamine deficiency. Cardiovasc. Res. 1980, 14, 537-540. [CrossRef] [PubMed]

87. Seligmann, H.; Halkin, H.; Rauchfleisch, S.; Kaufmann, N.; Motro, M.; Vered, Z.; Ezra, D. Thiamine deficiency in patients with congestive heart failure receiving long-term furosemide therapy: A pilot study. Am. J. Med. 1991, 91, 151-155. [CrossRef]

88. Hanninen, S.A.; Darling, P.B.; Sole, M.J.; Barr, A.; Keith, M.E. The prevalence of thiamin deficiency in hospitalized patients with congestive heart failure. J. Am. Coll. Cardiol. 2006, 47, 354-361. [CrossRef] [PubMed]

89. Schoenenberger, A.W.; Schoenenberger-Berzins, R.; der Maur, C.A.; Suter, P.M.; Vergopoulos, A.; Erne, P. Thiamine supplementation in symptomatic chronic heart failure: A randomized, double-blind, placebo-controlled, cross-over pilot study. Clin. Res. Cardiol. 2012, 101, 159-164. [CrossRef] [PubMed]

90. Smithline, H.A. Thiamine for the treatment of acute decompensated heart failure. Am. J. Emerg. Med. 2007, 25, 124-126. [CrossRef] [PubMed]

91. Shimon, I.; Almog, S.; Vered, Z.; Seligmann, H.; Shefi, M.; Peleg, E.; Rosenthal, T.; Motro, M.; Halkin, H.; Ezra, D. Improved left ventricular function after thiamine supplementation in patients with congestive heart failure receiving long-term furosemide therapy. Am. J. Med. 1995, 98, 485-490. [CrossRef]

92. Jain, A.; Mehta, R.; Al-Ani, M.; Hill, J.A.; Winchester, D.E. Determining the Role of Thiamine Deficiency in Systolic Heart Failure: A Meta-Analysis and Systematic Review. J. Card. Fail. 2015, 21, 1000-1007. [CrossRef] [PubMed]

93. Dinicolantonio, J.J.; Lavie, C.J.; Niazi, A.K.; O'Keefe, J.H.; Hu, T. Effects of thiamine on cardiac function in patients with systolic heart failure: Systematic review and metanalisys of randomized, double-blind, placebo-controlled trials. Ochsner. J. 2013, 13, 495-499. [PubMed]

94. Joncquel-Chevalier Curt, M.; Voicu, P.M.; Fontaine, M.; Dessein, A.F.; Porchet, N.; Mention-Mulliez, K.; Dobbelaere, D.; Soto-Ares, G.; Cheillan, D.; Vamecq, J. Creatine biosynthesis and transport in health and disease. Biochimie 2015, 119, 146-165. [CrossRef] [PubMed]

95. Rawson, E.S.; Venezia, A.C. Use of creatine in the elderly and evidence for effects on cognitive function in young and old. Amino Acids 2011, 40, 1349-1362. [CrossRef] [PubMed] 
96. Nascimben, L.; Ingwall, J.S.; Pauletto, P.; Friedrich, J.; Gwathmey, J.K.; Saks, V.; Pessina, A.C.; Allen, P.D. Creatine kinase system in failing and nonfailing human myocardium. Circulation 1996, 94, 1894-1901. [CrossRef] [PubMed]

97. Gordon, A.; Hultman, E.; Kaijser, L.; Kristjansson, S.; Rolf, C.J.; Nyquist, O.; Sylvén, C. Creatine supplementation in chronic heart failure increases skeletal muscle creatine phosphate and muscle performance. Cardiovasc. Res. 1995, 30, 413-418. [CrossRef]

98. Kuethe, F.; Krack, A.; Richartz, B.M.; Figulla, H.R. Creatine supplementation improves muscle strength in patients with congestive heart failure. Pharmazie 2006, 61, 218-222. [PubMed]

99. Cornelissen, V.A.; Defoor, J.G.; Stevens, A.; Schepers, D.; Hespel, P.; Decramer, M.; Mortelmans, L.; Dobbels, F.; Vanhaecke, J.; Fagard, R.H.; et al. Effect of creatine supplementation as a potential adjuvant therapy to exercise training in cardiac patients: A randomized controlled trial. Clin. Rehabil. 2010, 24, 988-999. [CrossRef] [PubMed]

100. Fumagalli, S.; Fattirolli, F.; Guarducci, L.; Cellai, T.; Baldasseroni, S.; Tarantini, F.; Di Bari, M.; Masotti, G.; Marchionni, N. Coenzyme Q10 terclatrate and creatine in chronic heart failure: A randomized, placebo-controlled, double-blind study. Clin. Cardiol. 2011, 34, 211-217. [CrossRef] [PubMed]

101. Harper, A.E.; Miller, R.H.; Block, K.P. Branched-chain amino acid metabolism. Ann. Rev. Nutr. 1984, 4, 409-454. [CrossRef] [PubMed]

102. Von Haehling, S.; Doehner, W.; Anker, S.D. Nutrition, metabolism, and the complex pathophysiology of cachexia in chronic heart failure. Cardiovasc. Res. 2007, 73, 298-309. [CrossRef] [PubMed]

103. Carubelli, V.; Castrini, A.I.; Lazzarini, V.; Gheorghiade, M.; Metra, M.; Lombardi, C. Amino acids and derivatives: A new treatment of chronic heart failure? Heart Fail. Rev. 2015, 20, 39-51. [CrossRef] [PubMed]

104. Opasich, C.; Aquilani, R.; Dossena, M.; Foppa, P.; Catapano, M.; Pagani, S.; Pasini, E.; Ferrari, R.; Tavazzi, L.; Pastoris, O.; et al. Biochemical analysis of muscle biopsy in overnight fasting patients with severe chronic heart failure. Eur. Heart J. 1996, 17, 1686-1693. [CrossRef] [PubMed]

105. Aquilani, R.; Opasich, C.; Gualco, A.; Verri, M.; Testa, A.; Pasini, E.; Viglio, S.; Iadarola, P.; Pastoris, O.; Dossena, M.; et al. Adequate energy-protein intake is not enough to improve nutritional and metabolic status in muscle-depleted patients with chronic heart failure. Eur. J. Heart Fail. 2008, 10, 1127-1135. [CrossRef] [PubMed]

106. Young, L.H.; McNulty, P.H.; Morgan, C.; Deckelbaum, L.I.; Zaret, B.L.; Barrett, E.J. Myocardial protein turnover in patients with coronary artery disease. Effect of branched chain amino acid infusion. J. Clin. Investig. 1991, 87, 554-560. [CrossRef] [PubMed]

107. Scognamiglio, R.; Negut, C.; Piccolotto, R.; Dioguardi, F.S.; Tiengo, A.; Avogaro, A. Effects of oral amino acid supplementation on myocardial function in patients with type 2 diabetes mellitus. Am. Heart J. 2004, 147, 1106-1122. [CrossRef] [PubMed]

108. Zulli, A. Taurine in cardiovascular disease. Curr. Opin. Clin. Nutr. Metab. Care 2011, 14, 57-60. [CrossRef] [PubMed]

109. Jong, C.J.; Azuma, J.; Schaffer, S. Mechanism underlying the antioxidant activity of taurine: Prevention of mitochondrial oxidant production. Amino Acids 2012, 42, 2223-2232. [CrossRef] [PubMed]

110. Ramila, K.C.; Jong, C.J.; Pastukh, V.; Ito, T.; Azuma, J.; Schaffer, S.W. Role of protein phosphorylation in excitation-contraction coupling in taurine deficient hearts. Am. J. Physiol. Heart Circ. Physiol. 2015, 308, H232-H239. [CrossRef] [PubMed]

111. Rosca, M.G.; Hoppel, C.L. Mitochondria in heart failure. Cardiovasc. Res. 2010, 88, 40-50. [CrossRef] [PubMed]

112. Schaffer, S.W.; Shimada-Takaura, K.; Jong, C.J.; Ito, T.; Takahashi, K. Impaired energy metabolism of the taurine-deficient heart. Amino Acids 2015, 48, 549-558. [CrossRef] [PubMed]

113. Schaffer, S.W.; Jong, C.J.; Ito, T.; Azuma, J. Role of taurine in the pathologies of MELAS and MERRF. Amino Acids 2014, 46, 47-56. [CrossRef] [PubMed]

114. Ito, T.; Schaffer, S.; Azuma, J. The effect of taurine on chronic heart failure: Actions of taurine against catecholamine and angiotensin II. Amino Acids 2014, 46, 111-119. [CrossRef] [PubMed]

115. Azuma, J.; Hasegawa, H.; Sawamura, A.; Awata, N.; Ogura, K.; Harada, H.; Yamamura, Y.; Kishimoto, S. Therapy of congestive heart failure with orally administered taurine. Clin. Ther. 1983, 5, 398-408. [PubMed] 
116. Azuma, J.; Sawamura, A.; Awata, N.; Ohta, H.; Hamaguchi, T.; Harada, H.; Yamagami, T.; Ishiyama, T.; Iwata, H.; Kishimoto, S. Therapeutic effect of taurine in congestive heart failure: A double-blind crossover trial. Clin. Cardiol. 1985, 8, 276-282. [CrossRef] [PubMed]

117. Beyranvand, M.R.; Khalafi, M.K.; Roshan, V.D.; Choobineh, S.; Parsa, S.A.; Piranfar, M.A. Effect of taurine supplementation on exercise capacity of patients with heart failure. J. Cardiol. 2011, 57, 333-337. [CrossRef] [PubMed]

118. Lysiak, W.; Lilly, K.; DiLisa, F.; Toth, P.P.; Bieber, L.L. Quantitation of the effect of L-carnitine on the levels of acid-soluble short-chain acyl-CoA and CoASH in rat heart and liver mitochondria. J. Biol. Chem. 1988, 263, 1151-1156. [PubMed]

119. Broderick, T.L.; Quinney, H.A.; Lopaschuk, G.D. Carnitine stimulation of glucose oxidation in the fatty acid perfused isolated working rat heart. J. Biol. Chem. 1992, 267, 3758-3763. [PubMed]

120. Broderick, T.L.; Panagakis, G.; DiDomenico, D.; Gamble, J.; Lopaschuk, G.D.; Shug, A.L.; Paulson, D.J. L-carnitine improvement of cardiac function is associated with a stimulation in glucose but not fatty acid metabolism in carnitine-deficient hearts. Cardiovasc. Res. 1995, 30, 815-820. [PubMed]

121. Mancini, M.; Rengo, F.; Lingetti, M.; Sorrentino, G.P.; Nolfe, G. Controlled study on the therapeutic efficacy of propionyl-L-carnitine in patients with congestive heart failure. Arzneimittelforschung 1992, 42, 1101-1104. [PubMed]

122. Anand, I.; Chandrashekhan, Y.; De Giuli, F.; Pasini, E.; Mazzoletti, A.; Confortini, R.; Ferrari, R. Acute and chronic effects of propionyl-L-carnitine on the hemodynamics, exercise capacity, and hormones in patients with congestive heart failure. Cardiovasc. Drugs Ther. 1998, 12, 291-299. [CrossRef] [PubMed]

123. Löster, H.; Miehe, K.; Punzel, M.; Stiller, O.; Pankau, H.; Schauer, J. Prolonged oral L-carnitine substitution increases bicycle ergometer performance in patients with severe, ischemically induced cardiac insufficiency. Cardiovasc. Drugs Ther. 1999, 13, 537-546.

124. Zhi-Cheng, J.; Bing-Xiang, W.; Jian-Qiang, P.; Xin-Li, L.; Lei, P.; Shui-Ping, Z.; Zai-Xin, Y.; Jian-Bin, G.; Qing-Yan, Z.; Jia-Ning, C.; et al. Effect of intravenous l-carnitine in Chinese patients with chronic heart failure. Eur. Heart J. Supp. 2016, 18, A27-A36.

125. Ferrari, R.; Merli, E.; Cicchitelli, G.; Mele, D.; Fucili, A.; Ceconi, C. Therapeutic effects of L-carnitine and propionyl-L-carnitine on cardiovascular diseases: A review. Ann. N. Y. Acad. Sci. 2004, 1033, 79-91. [CrossRef] [PubMed]

126. Ferrari, R.; De Giuli, F. The propionyl-L-carnitine hypothesis: An alternative approach to treating heart failure. J. Card. Fail. 1997, 3, 217-224. [CrossRef]

127. Visser, M.; Paulus, W.J.; Vermeulen, M.A.; Richir, M.C.; Davids, M.; Wisselink, W.; de Mol, B.A.; van Leeuwen, P.A. The role of asymmetric dimethylarginine and arginine in the failing heart and its vasculature. Eur. J. Heart Fail. 2010, 12, 1274-1281. [CrossRef] [PubMed]

128. Rector, T.S.; Bank, A.J.; Mullen, K.A.; Tschumperlin, L.K.; Sih, R.; Pillai, K.; Kubo, S.H. Randomized, double-blind, placebo-controlled study of supplemental oral L-arginine in patients with heart failure. Circulation 1996, 93, 2135-2141. [CrossRef] [PubMed]

129. Fontanive, P.; Saponati, G.; Iurato, A.; Volterrani, C.; Boni, A.; Piccioni, L.; Din, F.L. Effects of L-arginine on the Minnesota Living with Heart Failure Questionnaire quality-of-life score in patients with chronic systolic heart failure. Med. Sci. Monit. 2009, 15, CR606-CR611. [PubMed]

130. Hambrecht, R.; Hilbrich, L.; Erbs, S.; Gielen, S.; Fiehn, E.; Schoene, N.; Schuler, G. Correction of endothelial dysfunction in chronic heart failure: Additional effects of exercise training and oral L-arginine supplementation. J. Am. Coll. Cardiol. 2000, 35, 706-713. [CrossRef]

131. Aquilani, R.; Viglio, S.; Iadarola, P.; Opasich, C.; Testa, A.; Dioguardi, F.S.; Pasini, E. Oral amino acid supplements improve exercise capacities in elderly patients with chronic heart failure. Am. J. Cardiol. 2008, 101, 104E-110E. [CrossRef] [PubMed]

132. Scognamiglio, R.; Testa, A.; Aquilani, R.; Dioguardi, F.S.; Pasini, E. Impairment in walking capacity and myocardial function in the elderly: Is there a role for nonpharmacologic therapy with nutritional amino acid supplements? Am. J. Cardiol. 2008, 101, 78E-81E. [CrossRef] [PubMed]

133. Lombardi, C.; Carubelli, V.; Lazzarini, V.; Vizzardi, E.; Quinzani, F.; Guidetti, F.; Rovetta, R.; Nodari, S.; Gheorghiade, M.; Metra, M. Effects of oral amino Acid supplements on functional capacity in patients with chronic heart failure. Clin. Med. Insights Cardiol. 2014, 8, 39-44. [CrossRef] [PubMed] 
134. Cararo, J.H.; Streck, E.L.; Schuck, P.F.; Ferreira Gda, C. Carnosine and Related Peptides: Therapeutic Potential in Age-Related Disorders. Aging Dis. 2015, 6, 369-379. [PubMed]

135. Hipkiss, A.R.; Brownson, C. A possible new role for the anti-ageing peptide carnosine. Cell. Mol. Life Sci. 2000, 57, 747-753. [CrossRef] [PubMed]

136. Hipkiss, A.R. Carnosine and its possible roles in nutrition and health. Adv. Food Nutr. Res. 2009, 57, 87-154. [PubMed]

137. Culbertson, J.Y.; Kreider, R.B.; Greenwood, M.; Cooke, M. Effects of beta-alanine on muscle carnosine and exercise performance: A review of the current literature. Nutrients 2010, 2, 75-98. [CrossRef] [PubMed]

138. Baye, E.; Ukropcova, B.; Ukropec, J.; Hipkiss, A.; Aldini, G.; de Courten, B. Physiological and therapeutic effects of carnosine on cardiometabolic risk and disease. Amino Acids 2016, 48, 1131-1149. [CrossRef] [PubMed]

139. De Courten, B.; Jakubova, M.; de Courten, M.P.; Kukurova, I.J.; Vallova, S.; Krumpolec, P.; Valkovic, L.; Kurdiova, T.; Garzon, D.; Barbaresi, S.; et al. Effects of carnosine supplementation on glucose metabolism: Pilot clinical trial. Obesity 2016, 24, 1027-1034. [CrossRef] [PubMed]

140. Lombardi, C.; Carubelli, V.; Lazzarini, V.; Vizzardi, E.; Bordonali, T.; Ciccarese, C.; Castrini, A.I.; Dei Cas, A.; Nodari, S.; Metra, M. Effects of oral administration of orodispersible levo-carnosine on quality of life and exercise performance in patients with chronic heart failure. Nutrition 2015, 31, 72-78. [CrossRef] [PubMed]

141. Witte, K.K.; Nikitin, N.P.; Parker, A.C.; von Haehling, S.; Volk, H.D.; Anker, S.D.; Clark, A.L.; Cleland, J.G. The effect of micronutrient supplementation on quality-of-life and left ventricular function in elderly patients with chronic heart failure. Eur. Heart J. 2005, 26, 2238-2244. [CrossRef] [PubMed]

142. McKeag, N.A.; McKinley, M.C.; Harbinson, M.T.; Noad, R.L.; Dixon, L.H.; McGinty, A.; Neville, C.E.; Woodside, J.V.; McKeown, P.P. The effect of multiple micronutrient supplementation on left ventricular ejection fraction in patients with chronic stable heart failure: A randomized, placebo-controlled trial. JACC Heart Fail. 2014, 2, 308-317. [CrossRef] [PubMed]

(C) 2016 by the authors; licensee MDPI, Basel, Switzerland. This article is an open access article distributed under the terms and conditions of the Creative Commons Attribution (CC-BY) license (http://creativecommons.org/licenses/by/4.0/). 